\title{
PERLINDUNGAN KERAHASIAAN DATA INVESTOR UNTUK PENCEGAHAN KEBOCORAN DATA INVESTOR PADA PERUSAHAAN INOVASI KEUANGAN DIGITAL GOOLIVE
}

\author{
Muhammad Hatta Satria \\ University Malaya \\ Email:mr.hattas@gmail.com
}

\section{Abstract}

The alteration in the digitalization era changed social interactions and personal relationship. Technological advancements facilitate the activities of millennial generation, especially in investing. The investment that currently becomes trading topic is financial technology. One offinancial technology companies becoming the object of this research is Goolive engaged in agriculture using the equity crowdfunding system. Since it has lots of investors, this study aims to learn its security system in protecting investor data to avoid data leakage. This is a normative research using two approaches: statue and conceptual approaches. The result indicates that, first, Goolive digital financial innovation company abides by the Financial Services Authority Regulation Number POJK.04/2018 concerning Fund Disbursement Services through Equity Crowdfunding and in attempt to anticipate investors' data leakage, they limit data access, password usage, and changing password and verification. Second, hindrance faced by this startup companies is also experienced by other similar companies, namely the lack of human resources who are experts in cyber security. Third, financial technology dispute resolution can be carried out either by litigation (court) or non-litigation channels. The non-litigation process can be taken using the APS by means of Negotiation, Binding Opinion, Mediation, Conciliation, Adjudication and Arbitration.

Adanya perubahan era digitalisasi mengubah cara berinteraksi_inanc dan bubungan personal manusia. Kemajuan teknologi mempermudah aktivitas generasi milenial khususnya dalam berinvestasi. Investasi yang menjadi trading topic saat iniyaitu financial teknologi. Salah satu perusahaan teknologi financial yang menjadi objek penelitian 
ini adalah Goolive. Salah satu perusahaan financial teknologi yang bergerak dalam bidangpertanian ini menggunakan_inancequity crowdfunding (penggalangan dana). Adanya penggunaan finance crowdfunding, pastinya perusabaan Goolive memiliki investor cukup banyak dalam menjalankan bisnisnya. Sebingga tujuan penelitian ini untuk mengetahui_inanc keamanan perusahaan Goolive dalam melindungi data investor sebagai upaya menghindari kebocoran data. Penelitian ini adalah penelitian empiris dengan menggunakan metode wawancara dalam mengumpulkan data. Hasilpenelitian ini menunjukkan bahwa bahwa pertama perusahaan inovasi keuangan digital Goolive dalam ruang geraknya berdasarkan Peraturan Otoritas Jasa Keuangan Nomor / POJK.04/ 2018 Tentang Layanan Urun Dana Melalui Penawaran Saham Berbasis Teknologi Informasi (Equity Crowdfunding) dan dalam mengantisipasi adanya kebocoran data investor dengan membatasi pengaksesan data, penggunaan sandi rahasia, dan mengganti sandi serta verifikasi. Kedua, hambatan yang dialami perusahaan startup ini juga dirasakan oleh perusahaan-perusahaan startup yang lain yaitu minimnya sumber day a manusia yang abli dalam bidang cyber security. Ketiga, penyelesaian sengketa teknologi financial dapat dilakukan dengan jalur litigasi (pengadilan) ataupun jalur non-litigasi. Penyelesaian non-litigasi dapat ditempuh menggunakan APS dengan cara Negosiasi, Pendapat Mengikat, Mediasi, Konsiliasi, Adjudikasi dan Arbitrase.

Keywords: data confidentiality, digital innovation, data leakage

\section{Pendahuluan}

Gelombang revolusi dalam dunia digital saat ini terus berkembang. Kemajuan teknologi banyak menciptakan inovasi serta mengubah cara berinteraksi_inanc dan hubungan personal. Perkembangan teknologi digital mengalami kemajuan di semua aspek kehidupan dan ekonomi masyarakat dunia, seperti pendidikan, kesehatan, transportasi, ritel, hotel dan keuangan. Semua orang dapat mengakses berbagai aplikasi di dunia maya yang dapat mempermudah kehidupan manusia dengan menggunakan gadget dan internet. Generasi muda milenial lebih senang berinteraksi dengan menggunakan gadget termasuk melakukan transaksi jual beli ataupun melakukan pembayaran secara online. Generasi muda milenial lebih senang menjelajahi situs jual beli online daripada melakukan door to door, karena lebih mudah membandingkan harga dan lebih efisien waktu.

Perubahan gaya hidup modern memicu munculnya inovasi-inovasi gaya bisnis baru berbasis teknologi financial (tekfin). Kehadiran teknologi financial mempermudah masyarakat khususnya generasi milenial dalam bertransaksi keuangan dan membantu dalam mengakses produk-produk keuangan dengan mudah dan lebih praktis. Generasi milenial dapat melakukan transaksi keuangan tanpa harus langsung ke perusahaan financial ataupun melakukan antrian panjang 
contohnya pada layanan perbankan pada umumnya sebagaimana pernyataan dari Bill Gates "banking is necessary, banks are not".

Teknologifinancial dalam Peraturan Bank Indonesia Nomor 19/12/PBI/2017 merupakan penggunaan teknologi finance keuangan yang menghasilkan produk, layanan, teknologi, dan/atau model bisnis baru serta dapat berdampak pada stabilitas moneter, stabilitas finance keuangan, efesiensi, kelancaran, kemananan dan keandalan finance pembayaran. Penyelenggara teknologi financial yakni meliputi finance pembayaran, pendukung pasar, manajemen investasi dan manajemen resiko, pinjaman, pembiayaan dan penyedia modal, dan jasa financial lainnya.

Dua lembaga independen yaitu Bank Indonesia (BI) dan Otoritas Jasa Keuangan (OJK) memiliki kewenangan dalam mengatur dan mengawasi aktivitas teknologi financial di Indonesia yang kemudian oleh Otoritas Jasa Keuangan (OJK) disebut dengan Istilah perusahaan inovasi keuangan digital. Teknologi financial menyajikan jasa finance, jasa pinjam-meminjam uang antar para pihak di masyarakat (peer to peer lending / P2P Lending) dan equity crowd funding. Bank Indonesia mengawasi dan mengatur jalannya bisnis teknologi financial pembayaran. Sedangkan Otoritas Jasa Keuangan mengatur dan mengawasi jalannya bisnis teknologi financial pinjaman dan bisnis teknologi financial permodalan.

Telah banyak berdiri perusahaan inovasi keuangan digital di Indonesia dan dimanfaatkan oleh masyarakat. Tidak bisa dipungkiri bahwa hanya beberapa perusahaan saja yang terdaftar secara resmi dan mendapatkan izin dari Otoritas Jasa Keuangan. Berikut persentase teknologi financial yang terdata di Bank BJB:

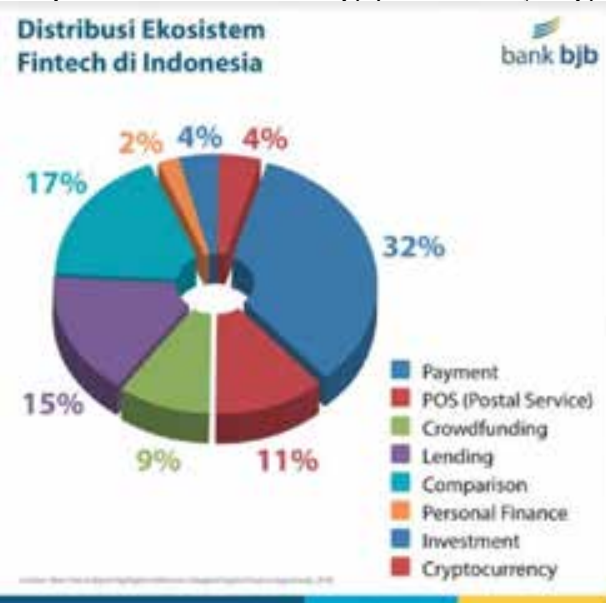

Gambar 1.

Fintech di Indonesia

Sumber : Bank BJB tahun 2018 
Tingginya pengguna layanan jasa teknologi financial membuat bisnis ini mempunyai dampak positif dan juga dampak negatif. Dampak positifnya adalah masyarakat semakin dekat dan mengenal lembaga keuangan yang ada di Indonesia. Sementara dampak negatifnya adalah adanya kebocoran data pribadi nasabah. Data pribadi adalah suatu asset berharga untuk bisnis dan organisasi yang terus menerus mengumpulkan, bertukar, mengolah, menyimpan dan bahkan menjual data pribadi sebagai komoditas, terutama yang berkaitan dengan konsumen. Dalam lingkup jaringan, sejumlah besar data pribadi sekarang dapat dikumpulkan dari pengguna internet dan dikumpulkan untuk membuat profil dari aktivitas online mereka dan referensi. Koleksi dan agregasi dapat berlangsung tanpa sepengetahuan pemilik data. ${ }^{1}$

Kasus kebocoran data nasabah menjadi sesuatu yang biasa terjadi dalam dunia lembaga keuangan bank maupun non-bank khususnya di Negara Indonesia, misalnya kasus sopir taksi yang bunuh diri karena meminjam uang dari salah satu pinjaman online. Bermula pada keterlambatan pembayaran sehingga menimbulkan berlipatnya bunga yang harus dibayar oleh nasabah dan bunga tersebut sangat tinggi sebagaimana yang dituliskan dalam dalam surat wasiat sopir tersebut sebelum akhirnya bunuh diri. Perusahaan online tersebut melimpahkan ke pihak kedua untuk melakukan penagihan dengan beserta data-data detail nasabah karena keterlambatan pembayaran hutang yang dilakukan nasabah. Tekanan, ancaman dan bunga yang besar dari debt collector yang membuat sopir taksi tersebut memilih untuk mengakhiri hidupnya. Kebocoran data yang demikianlah yang seharusnya dihindari oleh perusahaan-perusahaan inovasi keuangan digital yang sepatutnya melindungi atas hak privasi pengguna. Oleh karenanya Otoritas Jasa Keuangan sangat menekankan kepada pengguna jasa agar memilih layanan jasa simpan pinjam berbasis teknologi finansial yang telah terdaftar agar tidak terjadi hal-hal demikian. Otoritas Jasa Keuangan mengeluarkan Peraturan Otoritas Jasa Keuangan Nomor 77/POJK.01/2016 Tentang Layanan Pinjam Meminjam Uang Berbasis Teknologi Informasi agar tidak terjadi hal-hal yang dapat merugikan pengguna.

Salah satu perusahaan inovasi keuangan digital di Indonesia yang bergerak dalam dunia pertanian dan telah dimanfaatkan oleh masyarakat yaitu Goolive. Goolive ingin membangkitkan kembali kejayaan petani di negeri agraris dan maritim yang perannya dulu telah diakui oleh dunia. Sejak didirikan pada 15 Februari 2018, Goolive saat ini telah memiliki ratusan investor yang sudah terdata dan bergabung pada perusahaan inovasi keuangan digital tersebut. Oleh karenanya,

1 Syarpani, Mahendra Putra Kurnia, Safarni Husain, "Tinjauan Yuridis Terhadap Perlidungan Data Pribadi di Media Elektronik (Berdasarkan Pasal 25 UU No. 11 Tahun 2008 tentang Informasi dan Transaksi Elektronik)", (Online), Jurnal Beraja Niti, Vol. 3 Nomor 6, 2014, h. 6. 
dengan telah bergabungnya ratusan investor perlu adanya perlindungan data investor untuk menghindari kebocoran data karena hak setiap investor sebagai sponsorship untuk dilindungi hak privasi mereka.

Penelitian ini bertujuan untuk mengetahui peran perusahaan inovasi keuangan digital Goolive dalam melindungi data investor sehingga tidak terjadi kebocoran data, apa saja hambatan dalam upaya perlindungan data investor pada perusahaan inovasi keuangan digital goolive dan mekanisme penyelesaian sengketa finansial teknologi non-lembaga keuangan. Data pribadi investor yang telah diserahkan kepada perusahaan inovasi keuangan digital, menjadi kewajiban perusahaan inovasi keuangan digital untuk menjaganya sesuai perundang-undangan.

\section{Metode Penelitian}

Penelitian ini adalah penelitian yuridis empiris dengan pokok kajiannya adalah aturan-aturan hukum tentang teknologi financial, baik yang dikeluarkan oleh Otoritas Jasa Keuangan maupun Bank Indonesia yang dikonsepsikan sebagai perilaku nyata (actual behavior) sebagai gejala sosial yang sifatnya tidak tertulis, yang dialami setiap orang dalam hubungan hidup bermasyarakat. Penelitian ini mengkaji tentang cara perusahaan inovasi keuangan digital Goolive dalam melakukan perlindungan terhadap kerahasiaan data investor untuk pencegahan kebocoran data investor. Sumber data yang digunakan terdiri dari data primer yang diperoleh melalui wawancara dengan pimpinan Goolive, data sekunder berupa referensi buku-buku, artikel, jurnal dan penelitian yang setema. Data-data tersebut kemudian dianalisis menggunakan analisis deskriptif kualitatif.

\section{Pembahasan}

\section{Perlindungan Kerahasiaan Data Investor Untuk Pencegahan Kebocoran} Data Investor Pada Perusahaan Inovasi Keuangan Digital Goolive

Perlindungan hukum adalah segala pemberian bantuan dan upaya pemenuhan hak untuk memberikan rasa aman kepada korban dan/atau saksi, perlindungan hukum korban kejahatan merupakan bagian dari perlindungan masyarakat dan dapat diwujudkan dalam berbagai bentuk, seperti melalui pemberian kompensasi, restitusi, bantuan hukum, dan pelayanan medis. ${ }^{2}$ Perlindungan hukum baik yang bersifat preventif maupun represif diberikan kepada subjek hukum, baik yang lisan

2 Soerjono Soekamto, Pengantar Penelitian Hukum (Jakarta: UI Press, 1984), h.133. 
maupun yang tertulis. Dapat dikatakan bahwa perlindungan hukum memberikan suatu keadilan, kepastian, ketertiban, kemanfaatan dan kedamaian. Beberapa ahli mengungkapkan pendapatnya mengenai pengertian dari perlindungan hukum diantaranya:

Menurut Satjipto Raharjo perlindungan hukum adalah memberikan pengayoman kepada subjek hukum yang dirugikan orang lain dan perlindungan tersebut diberikan kepada masyarakat agar dapat menikmati semua hak-hak yang diberikan oleh hukum. ${ }^{3}$ Sedangkan menurut pendapat Philipus M. Hadjon perlindungan hukum adalah perlindungan harkat dan martabat, serta pengakuan terhadap hak-hak asasi manusia yang dimiliki oleh subjek hukum berdasarkan ketentuan hukum dari kesewenangan. ${ }^{4}$

Menurut pendapat Muchsin, perlindungan hukum merupakan kegiatan untuk melindungi individu dengan menyerasikan hubungan nilai-nilai atau kaidah-kaidah yang menjelma dalam sikap dan tindakan dalam menciptakan adanya ketertiban dalam pergaulan hidup antar sesama manusia. ${ }^{5}$ Menurut Setiono, perlindungan hukum adalah tindakan atau upaya untuk melindungi masyarakat dari perbuatan sewenang-wenang oleh penguasa yang tidak sesuai dengan aturan hukum, untuk mewujudkan ketertiban dan ketentraman sehingga memungkinkan manusia untuk menikmati martabatnya sebagai manusia. ${ }^{6}$

Menurut Hadjon, perlindungan hukum bagi masyarakat meliputi dua hal, yaitu: a) Perlindungan Hukum Preventif yaitu bentuk perlindungan hukum yang diberikan kepada rakyat dan diberi kesempatan mengajukan keberatan sebelum keluarnya keputusan pemerintah yang sifatnya definitive; b) Perlindungan Hukum Represifyaitu bentuk perlindungan hukum yanglebih ditujukan kepada penyelesaian sengketa. ${ }^{7}$ Pada dasarnya perlindungan hukum yang diberikan kepada rakyat Indonesia merupakan implementasi atas prinsip negara hukum yang berdasarkan Pancasila. Hakekatnya setiap orang berhak mendapatkan perlindungan dari hukum. Perlindungan hukum terbagi banyak macam, tetapi dari sekian banyak jenis perlindungan hukum terdapat beberapa diantaranya yang cukup popular dan tidak asing lagi seperti perlindungan hukum terhadap konsumen. Perlindungan hukum terhadap konsumen telah diatur dalam perundang-undangan dan pengaturannya

3 Satjipto Rahardjo, Ilmu bukum (Bandung: Citra Aditya Bakti, 2000 Cet ke-v), h.53.

4 Philipus M. Hadjon, Perlindungan Bagi Rakyat diIndonesia (Surabaya: PT.Bina Ilmu, 1987), h. 1-2.

5 Muchsin, Perlindungan dan Kepastian Hukum bagi Investor di Indonesia (Surakarta: Magister Ilmu Hukum Program Pascasarjana Universitas Sebelas Maret, 2003), h. 14.

6 Setiono, Rule of Law (Supremasi Hukum) (Surakarta: Magister Ilmu Hukum Program Pascasarjana Universitas Sebelas Maret, 2004), h. 3.

7 Philipus M.Hadjon, Perlindungan Bagi Rakyat diIndonesia, h. 5. 
mencakup banyak hal termasuk hak dan kewajiban antara produsen dan konsumen.

Perlindungan hukum bagi investor crowdfunding berbasis Teknologi finansial adalah isu utama dalam pengembangan bisnis penggalangan dana berbasis Teknologi finansial yang diatur dan diawasi oleh Otoritas Jasa Keuangan. Crowdfunding atau penggalangan dana adalah proses mengumpulkan sejumlah kecil uang untuk sebuah proyek atau usaha oleh sejumlah besar orang, biasanya dilakukan melalui platform online. Crowdfunding sendiri terdiri atas tiga jenis yang didasarkan pada bentuk imbalan yang diberikan pada pemberi dana, yaitu reward-based/donation-based crowdfunding, equity-based crowdfunding, dan loan-based crowdfunding.

Salah satu perusahaan teknologi finansial dalam hal crowdfunding atau penggalangan dana yang akan menjadi fokus kajian dalam artikel ini, yaitu perusahaan Goolive dari PT Sinergi Inti Berkah Investama. Perusahaan Goolive adalah equity crowfunding asal Indonesia untuk permodalan usaha tani yang bertujuan mensinergikan dunia pertanian dan semua potensi yang terkait di dalamnya untuk menghasilkan produk pertanian berkualitas tinggi yang aman, sehat dan halal serta ramah lingkungan. ${ }^{8}$ Goolive hadir sebagai sebuah platform digital yang bertujuan mensinergikan dunia pertanian dan semua potensi yang terkait di dalamnya untuk menghasilkan produk pertanian berkualitas tinggi yang aman, sehat dan halal. Berawal dari fakta di lapangan bahwa ada jutaan hektar lahan yang belum diproduktifkan secara optimal, sedangkan kebutuhan pangan masyarakat terus meningkat dan mengancam kedaulatan pangan dan berkaitan erat dengan krisis air bersih dan energi yang mengancam dunia secara global.

Goolive mengutamakan penanaman hasil pertanian yang dibutuhkan oleh pasar dan memilih harga yang paling relatif stabil. Kami menghubungkan petani dan lahan yang bisa dipergunakan, kemudian membuka peluang pembiayaan penanaman kepada para sponsorship. Goolive juga aktif mengedukasi masyarakat khususnya generasi muda dari berbagai latar belakang pendidikan untuk bersamasama bersinergi dalam menumbuhkembangkan kembali negara agraris dan maritim, serta menyediakan sumber pangan bermutu bagi umat manusia.

Sasaran investor dari Goolive, yaitu Setiap Warga Negara Indonesia (WNI) ataupun Warga Negara Asing (WNA) berusia minimal 17 tahun. Bagi para WNI, identitas diri dibuktikan melalui dokumen KTP, NPWP dan buku rekening bank yang kemudian difotokopi diserahkan pada saat mendaftar untuk bergabung sebagai investor di Goolive. Sedangkan bagi WNA melalui paspor dan rekening bank di Indonesia. Metode kuestioner digunakan untuk mendapatkan data-data yang diperoleh dari investor, seperti data keuangan, karakter investor dan sumber

8 Wawancara dengan Rifai Gurning (Direktur Goolive), 26 Maret 2019. 
dana investasi.

Berdasarkan hasil wawancara dengan Rifải Gurning selaku Direktur Goolive menyatakan bahwa perusahaan juga memerlukan data darimana calon investor memperoleh dana untuk berinvestasi di perusahaannya. Tujuannya adalah agar dana yang di investasikan di Goolive harus terjaga ke-halalannya sebagai upaya perusahaan menerapkan prinsip syariah sebagaimana misi perusahaan. Perusahaan Goolive tidak ingin dana yang di investasikan merupakan dana yang berasal dari hasil yang tidak halal atau hasil dari money laundring.

Cara bergabung dengan goolive; pertama, cukup melakukan registrasi online melalui website resmi http://goolive.id/register atau Aplikasi Goolive dari playstore dengan melengkapi data diri seperti nama, alamat email, dan password akun Anda. Kedua, setelah registrasi Anda akan menerima e-mail dari kami berisi sebuah link untuk memverifikasi alamat e-mail Anda. Jika Anda tidak menerima e-mail tersebut, silakan mengecek laman Spam. Anda dapat meminta agar e-mail verifikasi dikirimkan kembali melalui pengaturan akun Anda. Ketiga, jika anda siap mensponsori proyek kami. Anda akan diminta melengkapi data-data lainnya.

Setelah bergabung investor akan mendapatkan Skema bagi hasil Goolive yang bervariasi bergantung pada jenis unit proyeknya. Bagi hasil bersih adalah hasil rata-rata unit yang dikelola kemudian dikurangi dengan biaya-biaya operasional yang terkait pohon tersebut. Bagi hasil bersih ini kemudian secara umum dibagikan ke sponsor (40\%), petani/pengelola (40\%), dan independen surveyor dan administrator Goolive 20\%. Sebagian hasil tersebut akan disalurkan menjadi zakat, infaq dan sedekah

Perusahaan Goolive ini adalah dampak dari gerakan 1.000 start-up dan paket kebijakan ekonomi 14 yang dicanangkan pemerintah. Sehingga dalam penyelenggaranya Goolive berupaya agar tetap konsisten dalam memberikan perlindungan terhadap dana dan data konsumen. Keamanan data pribadi dan simpanannya sangat penting dalam layanan teknologi financial yang kegiatannya berhubungan dengan informasi keuangan. Semakin terhubung sistem teknologi informatika dengan berbagai institusi keuangan, maka akan semakin rentan sistem teknologi informatikanya. Perlindungan data pribadi pengguna juga diperlukan agar data privasi investor dapat disimpan dengan aman dan tidak dicuri oleh pihak lain seperti hacker, phising, virus, malware, dan seterusnya. Perlindungan konsumen dalam perihal data pribadi nasabah, hal ini menjadi sangat penting mengingat banyak terjadi penyalahgunaan data pribadi nasabah bank yang diduga dilakukan pihak ketiga yang mengaku telah bekerja sama dengan bank tempat nasabah meyimpan dana untuk menawarkan produk jasa keuangan. 
Sebagai ketentuan lembaga Otoritas Jasa Keuangan menerbitkan Peraturan Otoritas Jasa Keuangan (POJK) Nomor 1/POJK.07/2013 Tahun 2013 Tentang Perlindungan Konsumen Sektor Jasa Keuangan. Dalam Pasal 19POJK ini ditentukan bahwa Pelaku Usaha Jasa Keuangan (PUJK) dilarang melakukan penawaran produk dan/atau layanan kepada Konsumen dan/atau masyarakat melalui sarana komunikasi pribadi tanpa persetujuan Konsumen. Selain itu dalam Pasal 31 Ayat (1) POJK ini ditentukan bahwa Pelaku Usaha Jasa Keuangan dilarang dengan cara apapun, memberikan data dan/ atau informasi mengenai Konsumennya kepada pihak ketiga. Larangan tersebut dikecualikan dalam hal: Konsumen memberikan persetujuan tertulis; dan/ atau diwajibkan oleh peraturan perundang-undangan.

Data dan informasi diperoleh Pelaku Usaha Jasa Keuangan (PUJK) dari pihak lain dan akan menggunakan data tersebut untuk melaksanakan kegiatannya. PUJK wajib memiliki pernyataan tertulis bahwa pihak lain yang dimaksud telah memperoleh persetujuan tertulis dari sekelompok orang tersebut untuk memberikan data dan informasi pribadi dimaksud kepada pihak manapun, termasuk PUJK. Walaupun Teknologi finansial belum termasuk kategori Pelaku Usaha Jasa Keuangan, dalam pelaksanaannya apabila Teknologi finansial mengalami kendala maka dapat pula menggunakan peraturan tersebut sebagai dasar hukum. Otoritas Jasa Keuangan mengatur secara terknis dalam peraturan tersebut tentang perlidungan konsumen sektor jasa keuangan. Pengawasan kepatuhan PUJK dilakukan OJK sebagai penerapan ketentuan perlindungan yang meliputi pengawasan langsung dan tidak langsung.

Apabila para PUJK melanggar peraturan yang ditetapkan POJK, maka dapat dikenai sanksi dalam Pasal 53 POJK No. 1/POJK.07/2013. Pelaku yang melanggar ketentuan dapat diberikan sanksi sesuai dalam Peraturan Otoritas Jasa Keuangan ini dikenakan sanksi administratif, antara lain berupa:

a. Peringatan tertulis;

b. Denda yaitu kewajiban untuk membayar sejumlah uang tertentu;

c. Pembatasan kegiatan usaha;

d. Pembekuan kegiatan usaha; dan

e. Pencabutan izin kegiatan usaha.

OJK telah mengeluarkan surat edaran kepada pelaku usaha di sektor jasa keuangan tentang penerapan prinsip kerahasiaan dan keamanan data dan informasi pribadi konsumen. Data informasi pribadi konsumen yang harus dirahasiakan menurut Surat Edaran Nomor 14/SEOJK.07/2014 Tentang Kerahasiaan dan Keamanan Data dan/atau Informasi Pribadi Konsumen sebagai berikut: 
Perseorangan, terdiri dari:
1) Nama;
2) Alamat;
3) Tanggal lahir dan/atau umur;
4) Nomor telepon; dan/atau
5) Nama ibu kandung.

Korporasi:

1) Nama;

2) Alamat;

3) Nomor telepon;

4) Susunan direksi dan komisaris termasuk dokumen identitas berupa Kartu Tanda Penduduk/paspor/ijin tinggal; dan/atau

5) Susunan pemegang saham.

Menurut ketentuan di atas, pelaku usaha jasa keuangan dilarang memberikan dengan cara apapun mengenai data dan/atau informasi pribadi nasabahnya kepada pihak ketiga. Nomer telepon adalah salah satu data pribadi yang tidak boleh disebarluaskan oleh pelaku jasa keuangan kepada pihak ketiga di mana nasabah menyimpan dana. Meskipun demikian, ketentuan pelarangan tersebut dapat dikecualikan apabila:

a. Nasabah memberikan persetujuan tertulis; dan/atau

b. Diwajibkan oleh peraturan perundang-undangan.

Aspek perlindungan terhadap data pribadi merupakan salah satu hal penting yang harus dipertimbangkan oleh penyelenggara finansial teknologi. Pencurian data pribadi dapat berdampak penyalahgunaan data, penyalahgunaan profil konsumen, hingga resiko yang paling besar adalah ketidakpercayaan konsumen terhadap layanan finansial teknologi. Indonesia sejauh ini belum memiliki peraturan yang terkait tentang data pribadi (privacy data), seharusnya dengan berkembangnya teknologi dan meningkatnya berbagai macam model investasi, regulasinya juga harus dibangun agar tidak ada yang dirugikan salah satu pihak. Kebutuhan peraturan tentang privacy data adalah sebagai upaya untuk melindungi pengguna layanan finansial teknologi dari penyalahgunaan data.

Berdasarkan hasil wawancara dengan Rifa'i Gurning selaku Direktur Goolive perusahaan Goolive sudah mengetahui beberapa aturan-aturan terkait dengan kerahasiaan data investor bagi perusahaan inovasi keuangan digital. Sebagai perusahaan yang berusaha untuk mendapat izin resmi dari Otoritas Jasa Keuangan dan Bank Indonesia, Goolive berupaya selalu mematuhi peraturan yang

9 Marnia Rani, Perlindungan Otoritas Jasa Keuangan Terhadap Kerahasiaan dan Keamanan Data Pribadu Nasabah Bank, (Jurnal Selat: Oktober 2014, Vol. 2 No.1), h. 178. 
dikeluarkan oleh Otoritas Jasa keuangan dan Bank Indonesia. Misalnya dengan melakukan audit internal sehingga dapat mengevaluasi dan memahami tata kelola perusahaan yang baik serta meningkatkan efektivitas manajemen resiko.

Setiap SDM Goolive juga wajib mengerti dan menerapkan aturan terkait dengan kerahasiaan data investor karena hal itu adalah privacy. Perlunya perlindungan data investor untuk menghindari adanya penyalahgunaan data investor pengguna Teknologi finansial untuk kepentingan komersil perusahaan lain. Perlu diketahui bahwa data pribadi merupakan aset berharga untuk bisnis dan adapun organisasi yang berusaha untuk mengumpulkan, mengolah, bertukar, menyimpan dan bahkan menjual data pribadi sebagai komoditi usahanya. Koleksi dan Agregasi terjadi tanpa diketahui oleh pemilik data, ${ }^{10}$ sehingga data pribadi tersebar luas karena adanya transaksi jual beli data yang banyak terjadi di situs-situs jejaring internet yang berasal dari oknum-oknum yang tidak bertanggung jawab.

Upaya perusahaan inovasi keuangan digital Goolive dalam melindungi data-data investor yaitu dengan menyimpan data di folder khusus dan hanya bisa di akses petugas berwenang, penggunaan sandi khusus, serta mengaktifkan fitur securitynya SSL (Secure Socket Layer) pada web. Fungsi fitur security SSL sendiri adalah membuat channel yang aman antara pengguna browser dan server website yang terhubung sehingga menghindari adanya peretasan yang saat ini marak terjadi. Upaya kesadaran hukum dalam melindungi data konsumen telah dilakukan oleh perusahaan Inovasi Keuangan Digital Goolive sebagai bentuk kepatuhan terhadap peraturan yang telah ditetapkan POJK Nomor 1/POJK.07/2013 Tentang Perlindungan Konsumen Sektor Jasa Keuangan.

Pemeliharaan dan keamanan data harus dilakukan secara baik karena era digital ini relatif mudah untuk mencuri dan menghilangkan data. Untuk saat ini standar perlindungan perusahaan inovasi keuangan digital Goolive belum menggunakan ISO/ IEC 27001:2005 tentang infomation technology, security techniques, information security management system, requeirement merupakan suatu standar sistem manajemen keamanan informasi (ISMS, information security management system) yang diterbitkan oleh ISO dan IEC pada Oktober 2005. Namun tidak mengurangi standar operasional layanan, sistem, dan keamanan yang terbaik sebagai bentuk pelayanan kepada investor. Antisipasi adanya kebocoran data investor tentunya perusahaan inovasi keuangan digital Goolive membatasi pengaksesan data, penggunaan sandi rahasia, dan mengganti sandi serta verifikasi. ${ }^{11}$

10 Syarpani, Mahendra Putra Kurnia, Safarni Husain, Tinjauan Yuridis Terhadap Perlindungan Data Pribadi di Media Elektronik (Berdasarkan Pasal 25 UU No.11 Tahun 2008 tentang Informasi dan Transaksi Elektronik), (Samarinda: Jurnal Beraja Niti, Vol.3 Nomor 6, 2014), h. 6.

11 Pretty Kurniawati, Direktur Goolive, 26 Maret 2019. 


\section{Hambatan Goolive Sebagai Perusahan Inovasi Keuangan Digital Dalam Memberikan Perlindungan Data Investor}

Suatu semboyan Negara Indonesia sebagai Negara agraris adalah Gemah Ripah Loh jinawi yang memiliki arti kekayaan alam yang berlimpah. Ditinjau dari segi geografis, Indonesia merupakan Negara tropis yang dikelilingi banyak gunung dan memuntahkan bahan organik sehingga terkenal sebagai negeri yang subur, air yang melimpah dan sangat memiliki potensi yang besar dalam sektor pertanian. Sebagian penduduknya berprofesi sebagai petani menurut data Badan Pusat Statistik tahun 2009, jumlah petani mencapai 44\% dari total penduduk yang bekerja di Indonesia atau sekitar 46,7 juta jiwa. Namun pada tahun 2014 , jumlah petani di Indonesia mengalami penurunan yang drastis yakni berjumlah 35,54 juta jiwa. Penurunan 11 juta jiwa dalam masa 5 tahun merupakan angka yang cukup besar. Berawal dari sinilah perusahaan Inovasi Keuangan Digital Goolive lahir, rasa simpati karena prosentase penurunan angka petani inilah menggugah perusahaan Goolive untuk mensinergikan dunia pertanian dan semua potensi yang terkait di dalamnya sehingga menghasilkan produk pertanian berkualitas yang tinggi, aman, sehat, dan halal. Dengan menghasilkan produk pertanian yang berkualitas tinggi, perusahaan Goolive berharap hal ini bisa menaikkan kesejahteraan petani sehingga bisa menaikkan kembali angka prosentase petani yang setiap tahun terus menurun. Namun pada awal mula pendirian perusahaan Inovasi Keuangan Digital Goolive bukan tanpa rintangan, beberapa kali dipandang sebelah mata oleh calon investor. Kegigihan untuk menaikkan prosentase angka petani adalah alasan yang paling utama sehingga perusahaan startup ini pantang untuk menyerah dan terus belajar dari sebuah kesalahan.

Mekanisme pencatatan dan pendaftaran perusahaan Inovasi Keuangan Digital Goolive di OJK memerlukan jangka waktu yang lumayan panjang. Setiap penyelenggara inovasi keuangan digital, baik perusahaan startup ataupun lembaga jasa keuangan akan melalui 3 (tiga) tahap proses sebelum mengajukan permohonan perizinan yang tertuang dalam POJK Nomor 13/2018, yaitu: 1) Pencatatan kepada Otoritas Jasa Keuangan (OJK) untuk perusahaan startup/ non-Lembaga Jasa Keuangan. Permohonan pencatatan secara otomatis termasuk permohonan pengujian Regulatory Sandbox (ruang uji coba terbatas produk, layanan, model bisnis, dan teknologi dari fintech). Sedangkan untuk Lembaga Jasa Keuangan, permohonan Sandbox diajukan kepada pengawas masing-masing bidang (perbankan, pasar modal, industri keuangan non-bank).2) Proses Regulatory Sandbox memerlukan jangka waktu paling lama 1 tahun dan dapat diperpanjang selama 6 bulan bila diperlukan. 3) tahap selanjutnya bisa segera melakukan 
pendaftaran/perizinan kepada OJK.

OJK menetapkan penyelenggara inovasi keuangan digital wajib mengikuti proses Regulatory Sandbox. Hasil uji coba Regulatory Sandbox ditetapkan dengan status: direkomendasikan, perbaikan dan tidak direkomendasikan. Bagi penyelenggara yang sudah direkomendasikan dapat mendaftar ke OJK. Dengan terdaftarnya penyelenggara di $\mathrm{OJK}$, secara tidak langsung akan menimbulkan rasa kepercayaan bagi pengguna dalam berinvestasi. Oleh karenanya, penyelenggara wajib menjaga kepercayaan pengguna dengan menggunakan prinsip dasar perlindungan konsumen termasuk data nasabah, perusahaan inovasi keuangan digital juga harus menerapkan tata kelola perusahaan yang baik, seperti manajemen risiko sehingga mendorong transparansi, akuntabilitas, tanggungjawab, independensi dan keadilan.

Terbatasnya sumber daya manusia terkait dengan cyber security merupakan hambatan dan mempengaruhi dalam perekrutan karyawan pada perusahaanperusahaan inovasi keuangan digital khususnya Goolive. Mengingat keamanan data investor adalah salah satu bagian penting dalam suatu perusahaan startup selain modal sebagai wujud investasi. Kasus peretasan sudah menjadi isu hangat dalam perusahaan startup maupun lembaga keuangan, artinya tingkat cyber security di Indonesia masih tergolong massif, tercatatnya Negara Indonesia masuk dalam 10 besar Negara yang paling beresiko mengalami serangan cyber security. Untuk menghindari peretasan tentunya perusahaan start up yang satu ini memiliki cara tersendiri contohnya dengan upaya membatasi akses data, membatasi penyebaran data, penggunaan sandi rahasia, mengganti sandi secara berkala dan verifikasi.

\section{Mekanisme Penyelesaian Sengketa Teknologi Finansial}

Sengketa perdata antara investor dengan perusahaan inovasi digital keuangan juga bisa terjadi di teknologi finansial. Munculnya sengketa biasanya terjadi karena adanya ketidakpatuhan pada perjanjian para pihak. Mekanisme penyelesaian sengketa perdata teknologi finansial dapat diselesaikan melalui jalur litigasi (pengadilan) ataupun jalur non-litigasi (luar pengadilan). Alternatif Penyelesaian Sengketa (APS) atau jalur non-litigasi sering dipakai untuk menyelesaikan sengketa, karena buruknya reputasi pengadilan di Indonesia. Meskipun adanya himbauan dari Mahkamah Agung terkait proses peradilan saat ini berlangsung mudah, cepat, dan murah; faktanya tidak sedemikian adanya. Proses yang panjang berbelit-belit, mahal dan putusannya sulit di ekseskusi masih saja terjadi di dalam proses peradilan di Indonesia.

Putusan pengadilan bersifat menang dan kalah menjadi pertimbangan berikutnya bagi bagi investor dan penyelenggara, karena dapat mengakibatkan 
rusaknya hubungan bisnis. Alternatif Penyelesaian Sengketa lebih banyak diminati karena dinilai lebih efisien dan efektif. Pelaku bisnis dapat menggunakan beberapa model alternatif penyelesaian sengketa yaitu; negosiasi, pendapat mengikat, mediasi, konsiliasi, adjudikasi dan arbitrase. ${ }^{12}$ Adapun jika negosiasi gagal, para pihak dapat mengundang pihak ketiga untuk membantu menyelesaikan sengketa. Pihak ketiga dapat berstatus sebagai ahli hukum, mediator, conciliator, adjudikator dan arbiter. ${ }^{13}$

Sengketa teknologi finansial masuk pada ranah hukum perdata, yang dapat diselesaikan melalui litigasi (pengadilan) maupun non-litigasi (luar pengadilan). Gugatan di pengadilan membutuhkan proses yang cukup panjang, karena putusan di tingkat pengadilan negeri masih bisa diajukan banding ke Pengadilan Tinggi hingga tingkat kasasi ke Mahkamah Agung, sehingga jalur non-litigasi melalui Alternatif Penyelesaian Sengketa lebih banyak digunakan oleh pelaku bisnis. Penyelesaian sengketa model APS telah diatur UU 30/1999 tentang Arbitrase dan Alternatif Penyelesaian Sengketa yang mulai berlaku 12 Agustus 1999. ${ }^{14}$

Terbitnya Peraturan OJK nomor 1/ POJK.07/ 2014 tentang Lembaga Alternatif Penyelesaian Sengketa di sektor Jasa Keuangan dan disusul dengan keluarnya Keputusan OJK Nomor Kep-01/D.07/2016 tanggal 21 Januari 2016 yang mengesahkan pembentukan 6 (enam) Lembaga APS yaitu:

1. Lembaga Alternatif Penyelesaian Sengketa Perbankan Indonesia (LAPSPI)

2. Badan Arbitrase Pasar Modal Indonesia (BAPMI)

3. Badan Mediasi dan Arbitrase Asuransi Indonesia (BMAI)

4. Badan Arbitrase dan Mediasi Perusahaan Penjaminan Indonesia (BAMPPI)

5. Badan Mediasi Pembiayaan dan Pegadaian Indonesia (BMPPI)

6. Badan Mediasi Dana Pensiun (BMDP).

Penyelesaian sengketa tekfin dengan Alternatif Penyelesaian Sengketa dapat dilakukan dengan cara model Penyelesaian Sengketa Daring (PSD) atau Online Dispute Resolution (ODR). PSD merupakan hasil kolaborasi antara Alternatif Penyelesaian Sengketa dan Teknologi Informasi dan Komunikasi. Penyelesaian sengketa yang demikian dilakukan via internet, sehingga prosesnya lebih cepat, murah dan mudah. Negara-negara maju lebih dahulu mempraktekannya untuk menyelesaikan sengketa tekfin seperti AS, Canada, Uni Eropa, Australia, Jepang, Singapura.

Berdasarkan UU ITE, pembentukan lembaga PSD dimungkinkan karena

12 Iswi hariani dan Cita Yustisia Serfiyani, Perlindungan Hukum Dan Penyelesaian Sengketa Bisnis Jasa Pm-Tekfin, (Jurnal Legislasi Indonesia, Vol 14 No.3, 2017), h. 353.

13 Iswi hariani dan Cita Yustisia Serfiyani, Perlindungan Hukum Dan Penyelesaian Sengketa Bisnis Jasa Pm-Tekfin, h. 353.

14 Iswi Hariyani, Prosedur Mengurus HAKI Yang Benar (Yogyakarta: Penerbit Pustaka Yustisia Cet-1, 2010), h.26. 
saat ini semua data dan informasi dapat dijadikan bukti hukum. Lembaga PSD seharusnya dibentuk bukan hanya untuk kasus sengketa Pinjam Meminjam Teknologi Finansial, melainkan sengketa bisnis tekfin lainnya seperti crowdfunding. Perusahaan Goolive yang bergerak dalam dunia pertanian menggunakan sistem crowdfunding dalam menjalankan bisnisnya. Crowdfunding diartikan pendanaan beramai-ramai. Tujuan utama crowdfunding adalah alternatif bagi pelaku usaha untuk memperoleh pendanaan. ${ }^{15}$ Menurut Otoritas Jasa Keuangan (OJK) crowdfunding dikelompokkan dalam 4 (empat) jenis yaitu equity based crowdfunding (berbasis permodalan/kepemilikan saham), lending based crowdfunding (berbasis kredit / utang piutang), reward based crowdfunding (berbasis hadiah), dan donation based crowdfunding (berbasis donasi).

Konsep PSD harusnya dapat dipertimbangkan untuk dimanfaatkan di semua sektor teknologi finansial, baik itu mobile payment, pinjam meminjam dan crowdfunding karena mengingat keseluruhan data dan informasi konsumen telah terekam secara digital. Demikian apabila PSD akan dipertimbangkan dalam implementasinya, OJK harus segera mempersiapkan dasar hukum dari pelaksanaan PSD dan Penguatan kelembagaan LAPS.

\section{Simpulan}

Berdasarkan uraian yang telah dijabarkan dalam hasil penelitian dan pembahasan, dapat ditarik beberapa kesimpulan sebagai berikut: Perlindungan kerahasiaan data investor merupakan salah satu hal yang penting selain melindungi modal investasi. Menghindari adanya kelemahan tindakan hukum sepihak dalam berinvestasi di perusahaan finansial teknologi, perlu adanya keaktifan bahwa perusahaan tersebut tercatat di OJK atau belum. Hal ini untuk mendapatkan hak perlindungan konsumen bagi investor yang ingin berinvestasi di perusahaan finansial teknologi. Goolive sendiri hadir sebagai platform digital yang berbasis di bidang pertanian dan ingin memajukan pertanian Indonesia tentunya dalam ruang geraknya berdasarkan Peraturan Otoritas Jasa Keuangan Nomor / POJK.04/ 2018 Tentang Layanan Urun Dana Melalui Penawaran Saham Berbasis Teknologi Informasi (Equity Crowdfunding). Saat ini standar perlindungan perusahaan inovasi keuangan digital Goolive belum menggunakan ISO, tetapi tidak mengurangi standar operasional layanan, sistem, dan keamanan yang terbaik kepada investor. Antisipasi adanya kebocoran data investor dengan cara membatasi pengaksesan data, penggunaan sandi rahasia, dan mengganti sandi serta verifikasi. Dalam

15 Iswi hariani dan Cita Yustisia Serfiyani, Perlindungan Hukum Dan Penyelesaian Sengketa Bisnis Jasa Pm-Tekfin, h. 356. 
melindungi data investor pastinya terdapat hambatan yang tidak terhindarkan. Hambatan-hambatan ini juga menjadi pekerjaan rumah bagi perusahaan-perusahaan finansial teknologi khususnya yang baru berdiri. Minimnya sumber daya manusia dalam bidang cyber security menjadi hambatan utama bagi perusahaan Goolive. Penyelesaian sengketa dalam teknologi finansial seharusnya sudah dipersiapkan oleh pelaku usaha untuk mengantisipasi adanya ketidakpatuhan pada perjanjian para pihak. Penyelesaian sengketa tekfin dapat dilakukan menggunakan jalur litigasi (pengadilan) ataupun jalur non-litigasi (luar pengadilan). Penyelesaian non-litigasi dapat ditempuh menggunakan Alternatif Penyelesaian Sengketa dengan cara Negosiasi, Pendapat Mengikat, Mediasi, Konsiliasi, Adjudikasi dan Arbitrase. Di Negara-negara maju APS sudah banyak digunakan untuk menyelesaikan sengketa, khususnya dengan model Penyelesaikan Sengketa Daring (PSD) banyak diminati karena dinilai lebih mudah, murah dan efisien; dan penyelesaian sengketa yang demikian cukup dengan via internet.

\section{Daftar Pustaka}

\section{Buku}

Fidhayanti, Dwi. Urgensi Pembentukan Regulasi Shadow Banking Pada Layanan Pinjam Meminjam Teknologi Finansial Di Indonesia. Malang: UIN Maulana Malik Ibrahim Malang, 2018.

Hadjon, Philipus M. Perlindungan Bagi Rakyat diIndonesia. Surabaya: PT.Bina Ilmu, 1987.

Mantri, Bagus Hanindyo. "Perlindungan Hukum Terhadap Konsumen Dalam Transaksi E-Commerce”, Tesis, Semarang: Program Magister Ilmu Hukum, Universitas Diponegoro, 2007.

Muchsin. Perlindungan dan Kepastian Hukum bagi Investor di Indonesia.

Surakarta: Magister Ilmu Hukum Program Pascasarjana Universitas Sebelas Maret, 2003.

Rahardjo, Satjipto. Ilmu hukum. Bandung: Citra Aditya Bakti, 2000 Cet ke-V.

Setiono. Rule of Law (Supremasi Hukum). Surakarta: Magister Ilmu Hukum Program Pascasarjana Universitas Sebelas Maret, 2004.

Soekamto, Soerjono. Pengantar Penelitian Hukum. Jakarta: UI Press, 1984. 


\section{Artikel}

Iswi hariani dan Cita Yustisia Serfiyani. Perlindungan Hukum dan Penyelesaian Sengketa Bisnis Jasa Pm-Tekfin. Jurnal Legislasi Indonesia, Vol 14 No.3, 2017.

Rani, Marnia. Perlindungan Otoritas Jasa Keuangan Terhadap Kerahasiaan dan Keamanan Data Pribadu Nasabah Bank. Jurnal Selat: Oktober, Vol. 2 Nomor 1, 2014

Syarpani, Mahendra Putra Kurnia, Safarni Husain. Tinjauan Yuridis Terhadap Perlindungan Data Pribadi di Media Elektronik: Berdasarkan Pasal 25 UU No.11 Tahun 2008 tentang Informasi dan Transaksi Elektronik.. Jurnal Beraja Niti, Vol.3 Nomor 6, 2014. 